\title{
Moltmann's theology in dialogue with liberation theologians revives the role of Black Theology in democratic South Africa
}

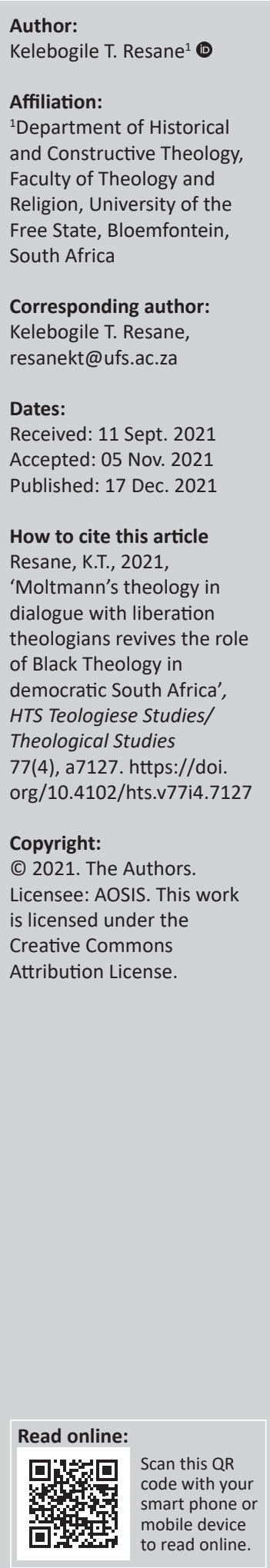

The theme for Liberation Theology has always been about concerns for the marginalised masses and socio-political liberation for the economically disadvantaged. Its mandate is to seek to guide towards the discovery of being human without references to historical divisions between the haves and have-nots created by socio-economic imbalances promoted by political regimes. Moltmann's content of theology, its revision, its innovation rather than the theological method has marked his restless imagination. His method of exploration in doing theology has brought him into dialogue with philosophers and theologians of different persuasions. In this study, he is evaluated in his dialogue with the liberation theologians. The focus is on Moltmann's theological approach to ecumenism, built around the Kingdom of God concept, and ecclesiastical analysis and political theology. These three areas are the transitional arguments on how Moltmann enters into dialogue with the liberation theologians. The argument moves on to point how Liberation Theology has exerted itself as Black Theology in South Africa during the apartheid time. Black Theology is a theology of liberation because of its resistance and endeavours of eradication of all forms of oppressive systems. The two injustices (socio-cultural misnomers) in the democratic South Africa are discussed as a calling for Black Theology's voice. These are corruption and human rights abuses. Black Theology brings religion into the secular world as a way of aborting all forms of discrimination based on race, sex and economic class.

Contribution: Black Theology is invited to revisit Moltmann's ecumenical, ecclesiastical and political theological understanding, as a way of reviving itself back to the centre stage of prophetic role within the corrupt and human rights and dignity abuse society.

Keywords: Moltmann; Liberation Theology; Black Theology; kingdom of God; politics; religion; dialogue.

\section{Introduction}

Liberation Theology is a religious movement that arose in the mid-20th century within the Roman Catholic Church in Latin America. Liberation theologies emanate less from the structured learning centres than from the grassroots societal levels. It is a social and political movement within the church, which aims to interpret the biblical message through the lived experiences of the poor and the oppressed masses. In other words, it seeks to apply religion by empowering the poor and the oppressed through political and civic affairs. In Liberation Theology, the socio-political experiences and abject poverty provoke the alternative reading of the Bible; especially when the ecclesial sacraments become politicised as weapons of social injustice. These ecclesial sacraments become 'political in the sense of being directly linked to the issue of emancipation from structural sin' (Gutierrez 1973:11). It emerged as a response to the socio-economic development pushing the peasant workers and rural farming populations to the periphery and the margins of economic development. When that kind of scenario develops, economic and political unrest can be expected, and these will always be met by political dictators unleashing brutality in the name of national security.

The mandate of Liberation Theology has always been concerns for the marginalised masses and socio-political liberation for the economically disadvantaged people. The early stages of Liberation Theologies in the 50s and 60s of the previous century has been a political engagement of Latin American theologians, such as Gustavo Gutierrez, Leonardo Boff, Juan Luis Segundo and Jon Sobrino. These theologians were known for the slogan: Preferential option for the poor. They were in broader composition, Catholics. However, some Protestant evangelicals joined 
the liberation theological option by promoting 'integral mission, emphasizing evangelism and social responsibility' (Clawson 2012:798). Names in this category include the likes of Rubem Alves, Jose Miguez Bonino and Rene Padilla.

According to this historical development and mandate, it can be concluded that Liberation Theology's theo-discourse is based on the historical and current experiences of the poor. It is a discourse that emerges from the 'experience that is dependent upon God's choosing to reveal himself in the poor' (Gutierrez 1984:4), and it is a 'critical reflection on revolutionary praxis limited to those who identify with the marginalised' (Berghoef \& DeKoster 1984:183). Or, even as asserted by Fierro (1977:88), it is a 'critical reflection in and on historical praxis'. It seeks to guide the transformation of all people into some newness of life that is beyond historical socio-economic structural divisions in the societies. Some researchers assume that this notion will make the poor richer, turning them into another societal structure of oppressors. However, the initial intention of Liberation Theology advocates a transformation of social structures that rid societies of the massive economic disparities and offer 'anthropologies of transformation stressing new ways of being human for all persons' (Chopp \& Regan [2005] in Ford \& Muers [2005:475-480]).

This theology critiques the structural and institutional poverty that is so closely associated with the modern Christianity that sounds and seems to be advocating riches by marginalising the poor or disregarding them. In response, Liberation Theology dialogues with philosophy and social sciences, with the dialogical objective of transformation in solidarity with the poor. It offers a:

$[T]$ heological anthropology that is political, an interpretation of Christianity that may be characterized through the term liberation, and a vision of Christianity as a praxis of love and solidarity with the oppressed. (Gutierrez 1984:6)

It is always logical to speak of this theology in plural as there are diverse branches of Liberation Theology, which include African Theology, Black Theology, Feminist Theology and lately Ecotheology. The spread of Liberation Theology took different formats in different parts of the world. For instance, Black Theology became rooted and popular in the United States of America and South Africa, while African Theology thrives in Africa and Feminist Theology in many parts of the world.

Political dictators or retractors felt uncomfortable with liberation theologies because in a wider sense, these theologies appeal to Marxist economic theory to validate the gospel. This approach views Jesus as the liberator who is always on the side of the poorest of the poor. This calls for liberation theologies to appeal for the reorganisation of social, political and economic structures so that the poor may 'feel cared for and also brought into the fullness of human flourishing, consequently, creating a new man in a classless society' (Berghoef \& DeKoster 1984:15). Liberation theologies kick the church out of the shell into the missional incarnation on the peripheries of the mainline elite society. The fundamental reality is that during these turbulent times when theology is pushed into the margins of social fabrics, contributions to a comprehensive theologia should be forthcoming out of the diverse quarters of human experiences.

\section{Moltmann's theological method opens dialogue with liberation theologians}

This study focuses on Moltmann's theological approach to ecumenism, built around the Kingdom of God concept, ecclesiastical analysis, and political theology. These three areas are the transitional arguments on how Moltmann enters dialogue with the liberation theologians. Reading and studying his works, conclusion is always that Moltmann's theological method follows an ecumenical collaboration. He dialogues with theologians of different traditions and persuasions, including those of the East and West orthodoxy, that is, Catholics and Orthodox, the Jews, Pentecostals and Charismatics, liberation theologians, etc. For him, these collaborations are an attempt towards a better understanding of Christian theology, which he believes should be deliberated inter-ecumenically. He dialogues and researches beyond Judeo-Christian circles by engaging with the philosophers and theologians, such as Augustine, Aquinas, Calvin and Newton.

Studying Moltmann's theology is a journey towards a discovery of what is in the minefield, an attempt into unchartered territory, even without any road map, only with curiosity. Many scholars will agree with me that his theological dictums are more adventurous than simple expeditions or excursions.

Since the publication of Theology of Hope in 1964, Moltmann's discovery journey has been dominated by the theme of eschatological hope, whereby the central theme is the coming Kingdom of God. Apart from the production of his famous trilogy, Theology of Hope (1964), The Crucified God (1972) and The Church in the Power of the Spirit (1975) that turned his theological journey, in 1978, he was one of the facilitators at the Mexico City conference engaging liberation theologians, black theologians and feminist theologians. His participation and contribution enhanced his universal theology. Meeks (1996:103) pointed out that Moltmann's primary theological interest is the revised content of theology in its biblical roots 'and in its innovation, given the challenges of the present' rather than the methodical questions or processes. His theological discovery journey is also marked by 'a restless imagination'.

Moltmann's theological analysis is through exploration. His theological method is never in the form of apologetical defence of patristic dogmas or ecclesiastical confessions. His manner of thinking is inventive and innovative. Moreover, he emphasises dialogical engagement and processes because dogma is ontologically dialogical. That is because Moltmann thinks that truth is to be found in 'unhindered dialogue rather than in theological systems and 
assertive dogmatics' (Moltmann 1981:xiii). Thus, for him theology is a 'common task, and theologians belong also to the communio sanctorum, in which justified sinners and accepted skeptics are gathered' (Meeks 1996:103). Furthermore, Moltmann believes that Christian theology emerges and experienced within the ecumenical fellowship, which transcends the present denominational, cultural and political formations. He demonstrates this conviction by dialogical involvement with Catholics, Orthodox Christians, Pentecostals, liberation theologians (ecotheologians, feminists, black theologians and African theologians) and Jews. Moltmann is therefore 'an innovator in theology'. For him, 'theology is imagination for the Kingdom of God in the world and for the world in the Kingdom of God'. ${ }^{1}$ The Kingdom of God is intertwined with the passion experienced in a community setting with Jesus at the centre.

\section{Moltmann's ecumenical approach accommodates liberation theologians}

Moltmann's trinitarian thought, certainly, has deeply affected his ecumenicity portraying men and women as the centre of any ecclesiastical discourse. His social doctrine of the Trinity focuses on the deliberate efforts to liberate the oppressed masses in the world, which is expressed by his statement that it is a 'theology of action that is obligated to love and serve' (Moltmann's 1981:7). His ecumenical circle expanded when he collaborated with Faith and Order Commission of the World Council of Churches - an endeavour that overshadowed and superseded his former dialogues with non-Christian dialogists. This expands the circle of his ecumenical, intra-Christian context for his systematic contributions. From the early 1970s, his ecumenical networks expanded because of international travels, regular discourses on human rights hosted by World Council of Churches and the World Alliance of Reformed Churches.

The Kingdom of God concept is expounded by Moltmann in his book, The Trinity and the Kingdom of God: The doctrine of God (1981). It is a motif that influences Moltmann's ecumenical approach to theological dialogues. It is ideal to highlight this concept to find how it impacts Moltmann's ecumenism. Moltmann's affirmation with the Liberation Theology is where he asserts that God is omnipresent in places 'where his Kingdom is desperately needed. That place is among the destitute' (Moltmann 1981:32), where community and relationship lifestyle is a norm. This is not just the preternatural relationship between the Creator and the creation, between God and humans. God desires some symbiosis with his creation and will, therefore, not marginalise those who struggle to enter this symbiotic relationship. This is a social relationality of God and humanity, where the church leads in bringing God to the suffering and the marginalised. Bentley (2005:334) pointed out to the fact that within the South African context, the Kingdom of God 'requires social responsibility' whereby church is called upon to minister to the needy. This notion is expanded by Moltmann (1996:323) that the Kingdom of God is 'where God is glorified'. This place is the creation where God-humanity interactions are possible. These interactions between humans of different theological persuasions are necessary for fullness of life.

According to Moltmann, the motive of the Kingdom transcends grace, where God is the only one who takes the initiative, and 'God's supreme will, to the motive of love and true reconciliation between two parties' (1981:53). Here, there should be a mutual will towards reconciliation between the Creator and creation. Furthermore, we can deduce, as Bentley (2005:327) also agreed that this is a journey that is 'travelled by both God and creation'. This is the telos, viewed by Moltmann (1981:220) as 'being the consummated Kingdom of God'.

As can be expected, Moltmann's Kingdom of God concept leans on a Trinitarian model of Joachim of Fiore described in terms of three developmental stages labelled by Bentley (2005:327), 'as the Kingdom of the Father, the Kingdom of the Son and the Kingdom of the Spirit'. Moltmann (1981:53) expressed this that God the Father in his kingdom opts 'to reveal God-self to creation'. The God who seeks relationship with creation invites the knowledge of the existence of God to enable the possibility of entering that relationship. The challenge is that in the Father's Kingdom, the revelation is not imposing whereby God asserts his authority and supremacy over creation but the mutual self-revelation of God to creation intertwine, leaving some space for creation to identify with the Creator, 'without God compromising His identity or divinity' (1981:59). The Father's Kingdom leads to the Son's Kingdom, where Jesus is 'locked in identity with the Father' (1981:70); as a result, the Son continues the work of the Father by being both the very God of the very God and the very human of the very human. It is in Jesus that the Creator-creation relationship transitions between the Creator from 'partnership' to 'friendship'. In the same vein, the Father's Kingdom leads to the Son's Kingdom, and the Son leads to the Spirit's Kingdom. The Trinitarian model is fully realised in its perichoretical character. Moltmann (1992:61) pointed out that the Spirit is the one that 'restores creation to its initial relational state with the Creator as creation responds favourably to God's offer of communion'. Through transformative work of the Spirit, God can transform creation into his habitat. The Creator-creation relational state is once again transformed into humanness, referred to by Moltmann (1981:220) as 'sons and daughters of God'. The Trinitarian Kingdom of God is understandably not an instant transformation 'but is an eschatological hope' (Bentley 2005:328). The Kingdom of God, as far as Moltmann is concerned, is the 'divinely promised fulfilment of God's glory in the full freedom in community of humans' (Olson 2013:455). The Kingdom of God is where and when 'God is merciful Father, not Lord; it is the kingdom of love and free participation, not obedience and submission, ... that may lead to monarchical tendencies' (1981:61). This approach aligns with the liberationists' view of God as the transformer 
of human condition by direct involvement with humans in their context.

It has become possible for liberation theologies to become the new ecumenical point of convergence for the different traditions, experiences and struggles. This is where hope is accounted for in a practical and concrete way. The Kingdom of God theology of Moltmann resonates well with the strong ecumenical tendencies found within the liberation theologies.

Closely related to Moltmann's ecumenical theology is his church theology based on the unity that is found in Christ's high priestly prayer in John 17 . The unity of the church is vital for Moltmann - liberation theologians dialogue. Dialogical partners without synchrony cannot dialogue at all. The ecumenicity of the Church is based on the truth, which is indiscriminately realised through Christ's sacrificial death on the cross. In Ecumenism Beneath the Cross (1975, 1977), Moltmann suggested two bases for Christian unity, namely, the 'internal and external bases'. The internal basis of Christian unity is the Johannine priestly prayers of Jesus: That They may be one, Father, just as you are in me and I am in you. May they also be in us so that the world may believe that you have sent me (John 17:21). Moltmann's experiences were defining in the formation of his thought on unity and hope. The heart of Christian unity in all its dimensions should be 'located in this prayer of Jesus' (Michael 2015:4). Secondly, the necessity of unity is based on the external stimulus. Moltmann (1977) observed:

The external stimulus for the communion of Christians upon earth lies in the catastrophic 'sufferings of this age'. Only through ecumenical communion within itself, can Christianity witness the peace of God to this divided, oppressed and disturbed world. (p. 314)

In this thought, Moltmann surmises that Christian unity exerts incarnational love and character of Christ by healing the world, feeding the poor, destroying racial, gender and denominational or religious walls of hostility. He expounded this when he saliently engaged the Pentecostals in dialogue, and greatly applauded their holistic pneumatology in The Spirit of Life (1992) where he continued to expound his ecclesiology in The Church in the Power of the Spirit (1977). After all, as far as Moltmann is concerned, theology is 'theology of freedom not of dependency and monarchism' (1981:126). The same principle can be applied in dialogue with the liberation theologians. The Lord's high priestly prayer for Christian unity meets the general human needs, and it is for this reason that Moltmann reiterates the importance of this prayer.

Moltmann's ecclesiology is both messianic and relational. By messianic, it is meant that it is 'christologically founded and eschatologically directed' (1977:13), or it is ecclesiology that is 'eschatological Christology' (1977:122). As an eschatological phenomenon, the church should combine Christian identity and social relevance in order to advance in the world. The church is expected to possess self-understanding from
God's perspective within the cosmic context. This is relational ecclesiology where everything that exists in 'a living history, including the triune God, exists in relation with others' (1977:125). The church does not live in and for itself. The members thereof exist for each other and give themselves for the world through the message of hope. Therefore, 'its message will also consist of empathic solidarity with fellow believers who suffer in their world's present systems' (Beck 2010:115).

In many of Moltmann's ecumenical dialogues, he emphasises the cross as the ecclesial unity. For him, church unity is based in the one Lord Jesus Christ, and more specifically, in his death on the cross. Regardless of proliferations, fragmentations and disagreements, the church is united under the cross. The Crucified God (1972) theology centres around the fact that ecumenical dialogue regarding the meaning of the cross has resulted in a deeper appreciation of the passion of God and the liberating strength that comes from discipleship with the crucified one. 'This fruitful dialogue about the cross of Christ could remain abstract and merely theoretical if it does not lead to the dialogue under the cross' (1974:83-84). Being under the cross is more than just the unification of the church, but also that the church should feature fellowship amidst persecution and tribulation. The church suffers in the hope of God's final salvation 'from all forms of injustice and death' (1972:85). One can observe the synergy of Moltmann and liberation theologians in this ecclesial understanding.

Not only ecumenical theology and ecclesiology can synergise Moltmann with the liberationists but also his Political Theology. The leading exponents of Political Theology in Europe are the German Catholics J.-B. Metz, Carl Schmitt and the German Protestant Jürgen Moltmann. These asserted that God's understanding and interpretation are practical and political issues. Change and interpretation are intertwined. In her evaluation of these theologians, Van Wyk (2015) alluded to the fact that:

$[H]$ uman and even revolutionary change is at root interpretative; and, especially when it comes to the reality of God, interpretation is primarily a matter of practical reorientation (conversion) and concrete action (transformation of individual and collective life). (p. 1)

However, in this study, Political Theology of Moltmann is discussed with a German jurist called Carl Schmitt in mind. In the book where he is one of the editors: Political Theology: Four Chapters on the Concept of Sovereignty (2013), Schmitt (2013) claimed that 'all modern concepts of the state are secularized political concepts' (p. 99). Political theology, as expounded by Schmitt, is understood as a history of concepts and changes in their meaning. According to Meier (1995:3), Schmitt calls this a 'sociology of concepts'. This emanated out of the post-World War II prevailing sentiment, especially in North America, where secularisation reigned supreme, ascribing to the notion that the source and meaning of life can be discovered in art, politics and cultural entertainment. Currently, there is a return of religion onto the public stage. 
Religion prevails and is considered relevant. Political Theology occupies the centre stage of dialogue for the renewed significance of religion in the world.

Repeated attempts to create one, unifying definition of political theology, show that the scope of the concept depends on the position of the researcher, and therefore, strongly 'differs in the range of inclusion and exclusion of the phenomena' (Marulewska 2014:1). Regardless of this, in the broadest sense, Political Theology means 'all possible relations between politics and religion or theology' (Hepp 1998:1105), and in this understanding, 'it is independent of the religious commitment of scholars, who equally well can be believing Christians as well as atheists fighting against the opium of the people' (Marulewska 2014:1). Political Theology is an attempt to understand the socio-political world and view how to address this world.

It has become a well-known fact that Political Theology is hesitant about finality of dichotomy between religious and secular spheres, between ideological concepts and praxis. Political Theology is essentially a counter-Enlightenment project, therefore, in affirmative side with the postmodern theorists. Political Theology is critical to secularism; which encompasses autonomy of a secular realm from religious interests.

Like all social scientific evolutionary processes, political theology has evolved over the few decades. Today, 'a new Political Theology involved a hermeneutical rather than a political category' (Van Wyk 2015:2). For Moltmann, new Political Theology is largely cushioned on a theology of hope; it is a theology of 'ethical and political anticipation' (Moltmann 2013:4; cf. Fiorenza 2013:37), and it is an ecumenical endeavour in a cosmic convergence of violence and injustice. Moltmann had always been oriented towards political action - leniency that has credited him for being one of the major catalysts of liberation theologies. He has been criticised for defining salvation and the Kingdom of God in terms of political activism and liberative ideals. Because of his messianic and relational view of the church, 'private piety with a goal of self-enrichment (the privatization of the Christian faith) receives negative assessment from him' (Moltmann 1964:308). The church's call is to be a slave to serve the outcasts and the oppressed. After all, 'God is the God of the poor, the oppressed and the humiliated' (1972:329). He states in The Experiment Hope (1975:46) that the hope that the Bible speaks about is 'valid for the hopeless not the optimists, for the poor not for the rich, for the downtrodden and the insulted, for the oppressed'. He further expresses this view in The Way of Jesus Christ (Moltmann 1989):

In the divided world destroyed by enmity, the one gospel has two faces, according to the group to which it turns. Jesus proclaims to the poor the kingdom of God without any conditions and calls them blessed because the kingdom is already theirs. But the gospel of the kingdom meets the rich with the call to conversion (Mark 1:15). (p. 102)
Moltmann (1981:7) views God as the God who 'stands in solidarity and preference with the poor'. This is evidenced by his theology that he terms a theology of action, obligated to love and serve. This theology is not a theoretical concept, but the emancipation of the marginalised masses and transformation of humanity and its living conditions. This point brings him closer to the liberation theologians; and it is this point that will put him on the same platform with them. As Olson (2013) pointed out:

Moltmann's critical involvement with liberation theologies of all kinds has made him a major influence in revolutionary and political theologies of the latter half of the twentieth century and the beginning of the twenty-first century. (p. 455)

\section{Liberation theology in democratic South Africa}

Both South African and USA's Political Theology, as tenets of Liberation Theology, lean towards a Marxist orientation as a way of overcoming racial and class bigotries. In these territories, Marxist analysis of structural analyses are centred around racism (black and other ethnic theologies), sexism (feminist theologies) and issues of ecology. These analyses struggle with tensions between rootedness in Christian religious experience and the applications employed by secularists and political elitists. Reactions to such extremes have led to new biblical hermeneutics and Christian applications with meaningful values within the structural injustices.

As mentioned above, South Africa encountered and experienced Liberation Theology through Black Theology. This theology views Jesus Christ as the Black Messiah, Strong Deliverer and Liberator who submitted himself to suffering experiences of the oppressed with the intention of transforming oppression into victory through his resurrection power. Blackness is regarded as a theme of self-revealing Christ with the purpose of liberating black humanity from the clutches of white dominance of racism in Africa. Black Theology like other Liberation Theologies claims to be committed to fighting all forms of oppressive practices whether economic inequality, racial discrimination, gender biases, political discrimination, cultural exclusion, religious marginalisation, human rights violation, etc. These are mostly the Third World menaces marked by 'human rights violations, discrimination of religious minorities, malnutrition and undernutrition, as well as environmental degradation and its impact on the poor' (Antonio 2012:36). South Africa is the late arrival of independence and democracy in Africa, and like the rest of the continent, it is faced with challenges such as socio-economic inequalities, political uncertainties, environmental degradation and religio-cultural injustices. In her democratic dispensation, South Africa still faces the issues of racism, national identity, gender biases and sexuality discrimination with other forms of cultural injustices, including economic exclusion based on resources distribution inequalities. These prevailing circumstances situate Black Theology in the relevant space to operate more vigorously and vivaciously like during the time of apartheid. This theology became the power behind 
the demise of Apartheid in South Africa, the rise of non-racial democracy and the political change through leaders, such as Desmond Tutu, Allan Boesak, Frank Chikane, Manas Buthelezi, Simon Maimela, Takatso Mofokeng, Mokgethi Motlhabi, Itumeleng Mosala and many others.

The last decade of the 20th century, which was the dawn from the rising hope of the coming socio-political changes in South Africa, emerged with the slow disappearance of the voice of the black theologians. Like many European societies, South Africa 'have moved towards religiously neutral model of liberal democracy' (Prešov in Petkovšek \& Žalec 2019:49). This unfortunate situation bred some prophetic incredulity into the new South Africa. The once vocally aggressive Black Theology against the oppressive system of apartheid fizzled out of the public domain. It was like democracy is now an achievement or utopia of some sort. The post-apartheid era is infested with inequalities, systemic poverty, escalating crimes, human abuses, etc. The victims are left out by the justice system, and the voice for them is not audible enough, and hence, the need for Black Theology's voice. Theological tasks are still needed as Maluleke (1998:3) asserts: 'Black Theology is first and foremost not about the powerful but about the powerless and the silenced'. It is ideal to highlight two socio-cultural misnomers in the democratic South Africa calling for the echo of the Black Theology.

Firstly, the democratic South Africa is now unfortunately known as a state of corruption. The gap between theology and politics is felt when corruption escalates in the deafening silence of churches. The prophetic voice of Black Theology of liberation is not heard 'in the corridors of political power centres' (Resane 2016:5). Politics of factionalism, careerism and patronage are gaining ground in the post-apartheid South Africa. The national religious conscience is dampened as evidenced by escalating criminal activities, especially children and women abuse. The theo-political dialogue is demobilised and paralysed regardless of the political and theological condemnations of these critical activities. Political corruption gains the fastest momentum and is covered with spiritual innuendos that are not consonant with theological construction.

Civil protests and industrial actions are mainly instigated by not only corruption, poverty and unemployment but also a lack of ecclesiastical capacity to provide moral compass to ethically straying nation. These issues, especially corruption, are a serious challenge. Chikane (2013) correctly points out that the:

$[H]$ igh rate of unemployment, poor service delivery and limited resources are the results of corruption ... and that when corruption happens in government or the public sphere, it affects the poor even more. (p. 219)

Resane (Hermans \& Van den Berg 2020:139) pointed out that 'poverty and unemployment inhibit the development of effective and efficient local governance'.
The current South African government's reputation is known for poor service delivery, ineffectiveness, incompetence and high levels of corruption that cripple the quality of life that is already descending into chaotic life experiences. Political incapacity to deal with corruption leads to economic meltdown, and this impedes service delivery, building towards poor output of investment and economic growth, and the flourishing of unofficial sector that violates tax regulatory laws. Corruption prompts the withdrawal of foreign donors, leading to social menaces, such as unemployment and poverty.

Corruption is an evil that uses a 'political power to destroy others for the purpose of defending or preserving the integrity of one's sick self' (Peck 1990:277). Corruption in government is a sign of weakness in the management of its public institutions, and that tolerating corruption leads to the spiralling of malfeasance to systemic levels. As Beaumont (2020:87) says, '[c]orruption is often perceived as nebulous and amorphous'. Its victims are not always individuals but societies, in general. It creates some fertile soil for thriving the socio-economic environment with symptoms, such as poverty, criminal activities and human restlessness. Chikane (2013:219) highlighted the fact that 'corrupt governments are like systems that leak. Even when you put public money into service provision, the money leaks out to benefit the better endowed first before the poor'. It also corrupts the core of 'human relationships, value systems and vision of life' (De Wet \& Kruger 2013:1). Unfortunately, in South Africa, corruption is cultivated and nourished through narcissistic and dictatorial insanity perpetuated by and within government mechanisms through politics of entitlement that enhances the redeployment system. I think the status quo (redeployment system) here tries to follow Lyndon Johnson's aphorism (Leon 2013:169): It's better to have her on the inside of the tent pissing out, than outside the tent pissing in. The ruling party has this mechanism as its solid modus operandi, as explained by Basson (2019):

Deployment to a government job is almost viewed as a reward for services rendered during the struggle against apartheid, and comrades, even those implicated in major allegations of wrongdoing, are given a soft landing elsewhere in government if the heat becomes too much in their incumbent jobs. There's seldom punishment for wrongdoing. (p. 65)

This system by its nature calls for Black Theology to revisit Moltmann's theology in order to discover its role and ways of returning to the centre of the prophetic platform that fights against corruption. Its engagement and endeavours should be by utilisation of the pulpit not only for spiritual upliftment where sermons are only about God or Christ. Preaching platforms should aggressively disseminate the anti-corruption messages. This means that the pulpit ministry or kerygma should 'include anti-corruption messages where corruption would be considered and categorised as sin and not just a socio-economic evil' (Jere 2018:7). This calls for the revival of Black Theology that listens to the poor through their popular piety and culture - the pursuit of justice that calls for institutions that will foster participation against 
marginalisation' (Catta in Ahern, Clark, Heyer \& Johnson 2016:8-12).

Secondly, human rights abuses are flourishing in the democratic South Africa. As mentioned above, the religious conscience seems to be dead where humans treat each other with contempt and hatred. Victims include children, women, the poor, orphans, widows, people with same-sex orientation and, of course, the foreigners. The daily news broadcasts carry rights abuses of some kind, and this has become a norm in the society that claims entrenchment of human rights in its Constitution.

Concerns remain about law enforcement officers' brutality, the discriminative treatment of the vulnerable migrants, refugees and asylum seekers, and recurring outbreaks of xenophobia violence. South Africa continues to reinforce the protection, and the advancement of the rights of people with sexuality orientation (LGBTQI + community). This is observed by those concerned and affected as important yet inconsistent as violence against these people sometimes receive no full justice from the courts of law. The Human Rights Watch reported in 2019 that:

Across South Africa, a high number of cases continued to be reported of corporal punishment, violence, abuse, neglect, and inequality involving children with disabilities, especially children with autism spectrum disorder and children with psychosocial and/or intellectual disabilities, by teachers and peers in schools and school hostels. ${ }^{2}$

The historical record of Black Theology in South Africa legitimises it to speak into the situations where human dignity is disregarded and undermined. It was born and necessitated by struggle for political emancipation. It was a struggle against apartheid and expressed through the Black Consciousness Movement that strove for the dignity and rediscovery of the identity of the oppressed Black South Africans. Black Theology is an authentic and honest biblical theology addressing an 'African black experience within the complexity of the meaning of blackness in South Africa' (Van Aarde 2016:5). It is a contextual theology that unapologetically engages current 'political powers and structures from an African context' (Van Aarde 2016:1). However, as Molobi (2010:12) says, 'it validates itself as being in the mainstream of the biblical and Christian tradition'. It can therefore address societal sins from the biblical point of view. Now is the time for Black Theology in South Africa to revisit its founding principle of redefining and reimaging its traditional systematic theology, and see how to translate dogma into praxis, from private to public. As Maluleke (1998) once highlighted:

Black Theology has always had intentions beyond 'the four walls' of the Christian Church on the one hand and the realm of the merely religious on the other. Therefore, if Black Theology was not public in its effect it was definitely public and political in its intent. (p. 1)

2.https://www.hrw.org/world-report/2019/country-chapters/south-africa.
The essence of Black Theology in South Africa is the 'expression of the entire black community from racism and all forms of dehumanization' (Hopkins 2005:171). In agreement with Saayman (1991:102), we are still 'waiting as South African Christians for the church as a whole in our country to adopt a Black agenda' that needs some dialogue. After all, 'Black Theology of liberation is a discourse of life' (Vellem 2015:2). It is a discourse that generally aims to 'identify human rights violations in the hope that we can convince somebody to do something about them...' (Gammon [2016:68] in Ahern, Clark, Heyer \& Johnston).

Moltmann's ecumenical approach calls for a dire need for dialogue, whether interreligious, or inter-faith where Black Theology should take a centre stage, not as a leader but as a dialogical partner. The armchair position that Black Theology has occupied since the dawn of democracy needs to be challenged on the basis that it is now more prophetically needed to address societal menaces bred by corruption leading to human rights abuses. In its historical focus on racism, it contributed enormously towards restoration of human dignity. Human dignity is now vulnerable, and Black Theology is supposed to raise its head. Moltmann's liberationists' ideals of theology becoming the mouthpiece for the marginalised should encourage Black Theology to look into the South African human dignity degradation, and enter the frays and become prophetic.

\section{Conclusion}

Revisiting Moltmann's ecumenical, ecclesiastical and political theological understanding can revive South African Black Theology, and bring it back to the centre stage of offering a new hope in the midst of corruption and human rights and dignity abuses so prevalent in the South African society. Its ecumenical character should promote the Kingdom of God as the church under one Lord Jesus Christ, and more specifically, in his death on the cross. Black theologians should aim for the meaning of the cross that will result in a deeper appreciation of the passion of God that can be leashed into the lives of the poor and the marginalised. Black Theology ecclesiality should be he the united effort to restore the world's fallen state, including the restoration of human dignity such as health, poverty alleviation and non-discriminatory ideals. Black Theology as a theology of liberation should vehemently be addressing corruption and human rights abuses. As a Political Theology, it should comprehend in order to analyse the socio-political landscape of South Africa and find how to address this landscape that is proliferated with corruption and dehumanisation. It should condemn human rights abusers by aligning itself affirmatively with human rights activism. It should publicly stand against those who claim that Political Theology promotes the autonomy of a secular realm from religious interests by bringing religion into the secular world as a way of aborting all forms of discrimination based on race, sex and economic class. It is not a theology of pie-in-the-sky, with a sole focus on the vertical aspect of 
religion but 'a theology which is expected to be equally concerned with this-worldly human needs' (Motlhabi 2008:47). It is a discipline that has a long way to go, but using Moltmann's ecumenical and trinitarian theology, Black Theology can contribute towards South African socioeconomic transformation for the benefit of the marginalised poor and the victims of human rights violations.

\section{Acknowledgements Competing interests}

The author declares that he has no financial or personal relationships that may have inappropriately influenced him in writing this article.

\section{Author's contributions}

K.T.R. is the sole author of this article.

\section{Ethical considerations}

This article followed all ethical standards for research without any direct contact with human or animal subjects.

\section{Funding information}

This research work received no specific grant from any funding agency in the public, commercial or not-for-profit sectors.

\section{Data availability}

Data sharing is not applicable to this article as no new data were created or analysed in this study.

\section{Disclaimer}

The views and opinions expressed in this article are those of the author and do not necessarily reflect the official policy or position of any affiliated agency of the author.

\section{References}

Antonio, E.P., 2012, 'Black theology and liberation theologies', in D.N. Hopkins \& E.P. Antonio (eds.), The Cambridge companion of black theology, pp. 33-43, Cambridge University Press, New York, NY.

Basson, A., 2019, Blessed by Bosasa: Inside Gavin Watson's state capture cult Jonathan Ball Publishers, Johannesburg.

Beaumont, M., 2020, The accidental mayor: Herman Mashaba and the battle for Johannesburg, Penguin Books, Cape Town.

Beck, T.D., 2010, The Holy Spirit and the renewal of all things: Pneumatology in Paul and Jurgen Moltmann, Wipf \& Stock Publishers, Eugene, OR.

Bentley, W., 2005, 'The Kingdom of God in Moltmann's eschatology: A South African perspective', Dutch Reformed Theological Journal = Nederduitse Gereformeerde Teologiese Tydskrif 46(3-4), 326-335.

Berghoef, G. \& DeKoster, L., 1984, Liberation theology: The church's future shock... Explanation, analysis, critique, alternative, Christian's Library Press, Grand Rapids, MI.

Catta, G., 2016. 'Learning from the poor: Pope Francis's deepening of the preferentia option', in K. Ahern, M.J. Clark, K.E. Heyer \& L. Johnston (eds.), Public theology and the global common good: The contribution of David Hollenbach, pp. 3-13, Orbis Books, Maryknoll, New York, NY.

Chikane, F., 2013, The things that could not be said: From A\{ids\} to Z\{imbabwe $\}$ Picador Africa, Johannesburg.

Chopp, R.S. \& Regan, E., 2005, 'Latin American liberation theology', in D.F. Ford \& R.R. Muers (eds.), The modern theologians: An introduction to Christian Theology since 1918, 3rd edn., pp. 469-484, Blackwell Publishing, Oxford.
Clawson, M., 2012, 'Misión integral and Progressive Evangelicalism: The Latin American influence on the North American emerging church', Religions 3(3), 790-807. https://doi.org/10.3390/rel3030790

De Wet, F.W. \& Kruger, F.P., 2013, 'Blessed are those that hunger and thirst for righteousness: Sharpening the ethical dimension of prophetic preaching in a context of corruption', Verbum et Ecclesia 34(1), 10. https://doi.org/10.4102/ ve.v34i1.722

Fierro, A., 1977, The militant gospel, transl. J. Drury, Orbis Books, Maryknoll, New York, NY.

Gammon, M.E., 2016, 'Human rights as an ecumenical problem', in K. Ahern M.J. Clark, K.E. Heyer \& L. Johnston (eds.), Public theology and the global common good: The contribution of David Hollenbach, pp. 62-71, Orbis Books, Maryknoll, New York, NY.

Gutierrez, G., 1973, A theology of liberation, transl. S.C. Inda \& J. Eagleson (eds.), Orbis Books, Maryknoll, New York, NY.

Gutierrez, G., 1984, 'Theology and spirituality in a Latin American context', Harvard Divinity Bulletin 14 (June-August), pp. 458-462.

Hepp, R., 1998, 'Theologie, politische', in J. Ritter (ed.), Historisches Wörterbuch der Philosophie, vol. 10, pp. 1105-1112, Schwabe, Basel.

Hopkins, D.N., 2005, Black theology USA and South Africa: Politics, culture, and liberation, Wipf and Stock Publishers, Eugene, OR.

Jere, Q., 2018, 'Public role of the church in anti-corruption: An assessment of the CCAP Livingstonia Synod in Malawi from a kenōsis perspective', Verbum et Ecclesia 39(1), a1776. https://doi.org/10.4102/ve.v39i1.1776

Leon, T., 2013, Opposite Mandela: Encounters with South Africa's icon, Jonathan Ball Publishers, Johannesburg.

Maluleke, T., 1998, Black theology as public discourse, Concept paper for the Academic Workshop Cape Town, 30 September - 02 October 1998, viewed 02 July 2020, from http://www.religion.uct.ac.za/sites/default/files/image_tool/images/113/Institutes/

Marulewska, K.,2014, 'Schmitt's political theology as a methodological approach', in A. Lisiak \& N. Smolenski (eds.), What do ideas do?, vol. 33, IWM Junior Visiting Fellows' Conferences, Vienna.

Meeks, D., 1996, God the economist: The doctrine of God and political economy, rev. Fortress Press, Minneapolis, MN.

Meier, C., 1995, 'Was ist politische theologie?', in J. Assmann (ed.), Politische Theologie zwischen Ägypten und Israel, pp. 3-18, J.B. Metzler Publishers, Munchen.

Michael, M., 2015, 'Jurgen Moltmann and the theology of the cross in the Johannine Priestly prayer', Scriptura 114(1), 1-12. https://doi.org/10.7833/114-0-1133

Molobi, V.M., 2010, 'The past and future of black theology in South Africa: In discussion with Maimela', Studia Historiae Ecclesiasticae 36(Supplement), 35-48.

Moltmann, J., 1964, Theology of hope, SCM Press, Bloomsbury.

Moltmann, J., 1972, The crucified God: The cross of Christ as the foundation and criticism of Christian theology, SCM Press, London.

Moltmann, J., 1974, On human being: Christian anthropology in the conflicts of the present, Fortress Press, Minneapolis, MN.

Moltmann, J., 1975, The experiment hope, SCM Press, London.

Moltmann, J., 1977, The church in the power of the Spirit, SCM Press, London.

Moltmann, J., 1981, The trinity and the kingdom of God: The doctrine of God, transl. M. Kohl, SCM Press, London.

Moltmann, J., 1989, The way of Jesus Christ: Christology in messianic dimension, Fortress Press, Minneapolis, MN.

Moltmann, J., 1992, The spirit of life: A universal affirmation, Fortress Press, Minneapolis, MN

Moltmann, J., 1996, The coming of God: Christian eschatology, Fortress Press, Minneapolis, MN.

Moltmann, J., 2013, 'Political theology in ecumenical contexts' in F. Schussler, F.K. Tanner \& M. Welker (eds.), Political theology: Contemporary challenges and future directions, pp. 1-12, Westminster John Knox Press, Louisville, KY.

Motlhabi, M., 2008, African theology/black theology in South Africa: Looking back, moving on, Unisa Press, Pretoria.

Olson, R.E., 2013, The journey of modern theology: From reconstruction to deconstruction, InterVarsity Press, Downers Grove, MI.

Prešov, M.V., 2019, 'Living the faith in the secular world: Lessons from Charles Taylor', in R. Petkovšek \& B. Žalec (eds.), Religion as a factor of intercultural dialogue, pp. 49-57, LIT VERLAG GmbH \& Co., Zurich.

Resane, T., 2020, 'Who has the authentic voice to change the heart of communities: The church or government?', in C.A.M. Hermans \& J.-A. Van den Berg (eds.), Battle for the heart: How (not) to transform church and society, pp. 137-150, LIT Verlag, for the

Schmidt, C., 2013, Political theology, rev. edn., Antelope Hill Publishing, Albuquerque, NM.

Van Aarde T., 2016, 'Black theology in South Africa - A theology of human dignity and black identity', HTS Teologiese Studies/Theological Studies 72(1), a3176. http:// doi.org/10.4102/hts.v72i1.3176

Van Wyk, T., 2015, 'Political theology as critical theology', HTS Teologiese Studies/ Theological Studies 71(3), Art. \#3026, 8 pages. http://doi.org/10.4102/hts. v71i3.3026

Vellem V.S., 2015, 'Unshackling the Church', HTS Teologiese Studies/ Theological Studies 71(3), Art. \#3119, 5 pages. http://doi.org/10.4102/hts.v71i3.3119 